\title{
Abundance and distribution of invertebrate larvae in the Bellingshausen Sea (West Antarctica)
}

\author{
J. Ameneiro ${ }^{1}$, B. Mouriño-Carballido ${ }^{1}$, J. Parapar $^{2}$, E. Vázquez ${ }^{1}$ \\ ${ }^{1}$ Dpt. Ecoloxía e Bioloxía Animal, Facultade de Ciencias do Mar, Universidade de Vigo, Vigo, Spain \\ ${ }^{2}$ Dpt. Bioloxía Animal, Bioloxía Vexetal e Ecoloxía, Facultade de Ciencias, Universidade da Coruña, A \\ Coruña, Spain
}

Polar Biology, September 2012, Volume 35, Issue 9, pp 1359-1373

Received: 8 November 2011 / Revised: 20 March 2012 / Accepted: 22 March 2012 / Published online: 7 April 2012

\section{Cite this article as:}

Ameneiro, J., Mouriño-Carballido, B., Parapar, J. et al. Polar Biol (2012) 35: 1359. doi:10.1007/s00300-012-1177-4

The final publication is available at Springer via http://dx.doi.org/10.1007/s00300-012-1177-4

\begin{abstract}
The central part of the Bellingshausen Sea has been poorly studied, partly because of the presence of ice during most of the year. The main aim of this study was to analyse the abundance and distribution of meroplankton, and the influence of oceanographic properties were investigated in the Bellingshausen Sea (West Antarctica) during the BENTART-06 cruise carried out in January-February 2006. Zooplankton samples were collected with a $80-\mu \mathrm{m}$ mesh plankton net hauled vertically from a depth of $200 \mathrm{~m}$ to the surface at fifteen stations across the Bellingshausen Sea. Fifteen types of larval benthic invertebrates were found, with echinospira and nudibranch veligers being the most abundant. Hierarchical analysis and non-metric multidimensional scaling revealed a high degree of spatial variability in both larval abundance and larval types across the Bellingshausen Sea. The variability was significantly correlated with total chlorophyll- $a$ and the contribution of large ( $>5 \mu \mathrm{m})$ phytoplankton to total chlorophyll, indicating the availability of food as an important factor determining the larval distribution observed. Nudibranch veligers, nemertean pilidia, echinoderm and planula larvae were more abundant at stations in the central Bellingshausen Sea, which was characterized by low phytoplankton biomass and production. Higher abundances of echinospira veligers and polychaete larvae were found at the more productive stations close to Peter I Island and the Antarctic Peninsula. The abundance and diversity of larval types found in the Bellingshausen Sea during the BENTART-06 cruise support the hypothesis that indirect development through larval swimming stages plays a key role in benthic recruitment in polar areas.
\end{abstract}

\section{Keywords}

Bellingshausen Sea; Antarctica; Invertebrate larvae; Distribution; Diversity 


\section{Introduction}

The Antarctic environment is one of the most thermally stable environments on earth (Peck et al. 2006). However, despite the important regional differences, it is characterized by a high degree of seasonal variability in other physical factors such as light availability, sea-ice cover between summer and winter and a strong seasonality in primary production, which peaks during the summer months (Peck et al. 2006). This seasonality determines the abundance and distribution of pelagic fauna (Kaufmann et al. 2003) as well as other biological responses including seasonal changes in feeding activity, growth and reproduction (Sewell and Jury 2011). The pelagic community consists of a permanent component (holoplankton) and a temporary component composed by larval stages of benthic animals (meroplankton).

Although most benthic invertebrates display indirect development, with pelagic larval stages at temperate latitudes, the lack of larvae in polar waters led to believe that Antarctic benthic invertebrates reproduce without a planktonic stage (Murray 1895; Thorson 1950). However, recent studies in the Southern Ocean have revealed a relatively high diversity and abundance of larval forms (Shreeve and Peck 1995; Stanwell-Smith et al. 1999; Arntz and Gili 2001; Absher et al. 2003; Sewell 2005; Freire et al. 2006; Vázquez et al. 2007; Bowden et al. 2009), some of which are planktotrophic. Moreover, some of the most abundant species in these cold-water habitats reproduce seasonally, usually in late winter and early spring, so that the planktotrophic larvae coincide with the summer phytoplankton bloom (Pearse et al. 1991; Stanwell-Smith et al.1999; Pearse and Bosch 2002; Pearse and Lockhart 2004; Bowden et al. 2009).

The Bellingshausen Sea (BS) constitutes the third largest sea in the Southern Ocean, extending between Alexander Island and Thurston Island. Although it constitutes a natural connection between the Weddell and Ross seas, and therefore represents a natural means of dispersion of species in Antarctica, the Bellingshausen Sea is one of the least well studied areas in the Southern Ocean, owing to the presence of ice during most of the year (Clarke and Johnston2003; Assmann and Timmermann 2005).

Most of the research on Antarctic zooplankton communities in this region has been carried out in the Western Antarctic Peninsula (Ashjian et al. 2004; Calbet et al. 2005; Freire et al. 2006; Bowden et al. 2009; Mahon et al. 2010). However, in the BS, few studies have described the abundance and distribution of holoplankton during early summer (November-December) (Burkill et al. 1995; Weeks et al. 1995), and the study by Shreeve and Peck (1995) is the only one dealing with meroplankton distribution. These authors sampled five stations from the continental shelf to open ice-free waters along $85^{\circ} \mathrm{W}$, with a net of mesh size $200 \mu \mathrm{m}$, collecting sixteen different types of larval and juvenile specimens representing seven phyla, of which Echinodermata and Nemertea were the most abundant. They also described a decrease in both larval abundance and diversity towards offshore waters and away from the permanent sea ice.

The aim of the present study is to provide an overview of the scarcely studied diversity, abundance and distribution of pelagic larvae in the Bellingshausen Sea, and to investigate potential relationships with the oceanographic conditions observed during the BENTART-06 cruise.

\section{Materials and methods}

Field sampling 
Within the framework of the BENTART-06 project (an integrated study of the benthic ecosystem in the Bellingshausen Sea), we sampled sixteen stations on board RV Hespérides, between January and February 2006, ranging from the Antarctic Peninsula to Thurston Island (Fig. 1). Sampling covered four geographically well-characterized areas: Peter I Island (PI), the central Bellingshausen Sea (BS), Marguerite Bay (MB) and the Antarctic Peninsula (AP).

Conductivity-temperature-depth (CTD) profiles were recorded, with a Neil Brown mark III probe attached to a rosette equipped with Niskin bottles at all stations except 33 and 35 (where recording was not possible due to adverse weather conditions). Samples were collected to determine dissolved oxygen and size-fractionated chlorophyll- $a$ concentrations and to measure net community production. Dissolved oxygen was determined by the classical Winkler titration method, according to WOCE methodology (Culberson 1994), using the whole bottle with visual end-point titration with a starch solution. Chlorophyll- $a$ was determined after concentration of particulate matter by filtering $250 \mathrm{ml}$ of seawater through 5 and $2 \mu \mathrm{m}$ polycarbonate and GFF filters, which were immediately frozen. The concentration of size-fractionated chlorophyll- $a$ was measured on shore with a SAFAS flx spectrofluorometer calibrated with a pure chlorophyll-aextract obtained by HPLC, after extraction with $90 \%$ acetone overnight. Chemically determined chlorophyll- $a$ concentrations were used to calibrate the CTD fluorometer (chlorophyll- $a=1.0076 \times$ fluorescence $-0.1112\left(R^{2}=0.91\right)$ ).

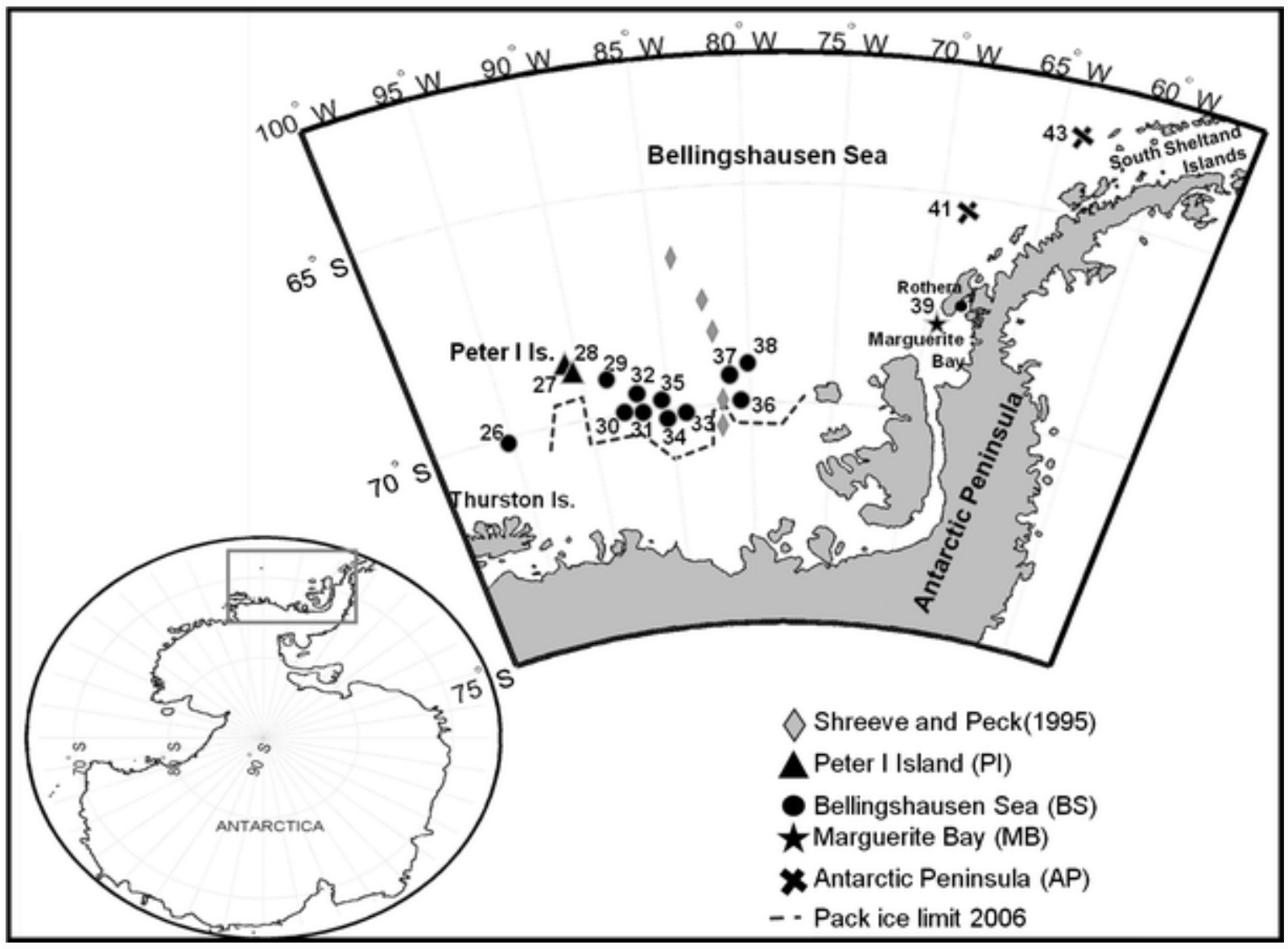

Fig. 1 Location of sampling stations in the Bellingshausen Sea (West Antarctica) sampled during the BENTART-06 cruise, in January-February 2006. Sampling covered four areas: the Antarctic Peninsula (AP), Marguerite Bay (MB), the central Bellingshausen Sea (BS) and Peter I Island (PI). Grey diamonds show the sampling stations referred by Shreeve and Peck (1995). The dotted line shows the limit of the pack ice during the survey, following San Vicente et al. (2009). Plankton samples were not collected at station 41, and the CTD probe was not deployed at stations 33 and 35 
Twelve experiments were carried out to determine Net Community Production (NCP), Community Respiration (R) and Gross Primary Production (GPP) from in vitro changes in dissolved oxygen during 24-h light/dark bottle incubations. Water samples were collected from a 24-bottle rosette (10$\mathrm{dm}^{3}$ PVC Niskin bottles) through silicon tubing into calibrated borosilicate glass bottles, with a nominal volume of $120 \mathrm{~cm}^{3}$. Four to five depths were chosen according to the profiles of fluorescence and photosynthetically available radiation (PAR). Four clear and four dark bottles from each depth were incubated for $24 \mathrm{~h}$ in an on-deck incubator covered with blue filters simulating the light field experienced by the cells at the original sampling depths. The bottles were placed in a on-deck flowthrough incubator refrigerated with running seawater pumped from the surface. Four replicate bottles were fixed immediately after the start of the incubation experiments in order to quantify the initial oxygen concentrations. Measurements of dissolved oxygen were made with an automated Winkler titration system, on the basis of a potentiometric end-point detector (Culberson 1994). Details of the methods are described in Mouriño-Carballido and McGillicuddy (2006). Depth-integration values were computed to a depth of $80 \mathrm{~m}$ for chlorophyll- $a$, and to $1 \%$ of PAR for NCP, R and GPP.

A total of 15 zooplankton samples were collected by use of a $80-\mu \mathrm{m}$ mesh plankton net with a 0.28 m-diameter mouth, at all stations except station 41 where sampling was not possible because of adverse weather conditions. Sampling was performed by vertical trawling from $200 \mathrm{~m}$ to the surface, except at station 39, the shallowest station, where trawling was carried out between $100 \mathrm{~m}$ and the surface. The plankton net was towed at a constant speed of $10 \mathrm{~m} \mathrm{~min}^{-1}$. The larvae collected were normalized to larvae $\mathrm{m}^{-3}$ in order to facilitate the comparison with previous studies in the region (Shreeve and Peck 1995; Stanwell-Smith et al.1999; Freire et al. 2006; Vázquez et al. 2007; Bowden et al. 2009; Sewell and Jury 2011). The volume of water passing through the net was calculated from a flow meter attached to the centre of the net mouth. The mean filtered volume was $15.6 \pm 2.6 \mathrm{~m}^{3}$.

\section{Laboratory study}

Zooplankton samples were anaesthetised with menthol crystals in seawater for $1 \mathrm{~h}$ prior to fixation. The samples were fixed with $40 \%$ formaldehyde to a final concentration of $4 \%$ formalin in seawater.

Total samples were examined under a binocular microscope, and larval stages were separated from zooplankton. Larvae were sorted, identified and quantified to a high taxonomic level (because of difficulties in identification) following descriptions provided in the literature (Stanwell-Smith et al. 1997; Young 2002; Sewell 2006). Euphausiid larvae were identified according to their developmental stages (Gibbons et al. 1999).

Nonparametric multivariate techniques were performed with the PRIMER v 6.0 statistical package (Clarke and Gorley 2006) to investigate differences in the types of larvae found at the different stations. A similarity matrix was constructed for samples by means of Bray-Curtis similarity index, by use of fourth-root-transformed larval-type abundances (larvae $\mathrm{m}^{-3}$ ) to down-weight the contribution of the most abundant taxa. From this matrix, the stations were classified by the groupaverage sorting algorithm. Non-metric multidimensional scaling, MDS, was used to evaluate the group separation derived from the cluster analysis.

In order to select the set of hydrographical features that best explain the distribution pattern of meroplankton, the BIO-ENV test (Clarke and Ainsworth 1993) of the PRIMER package was used. The BIOENV routine was carried out by superimposing the physical data (similarity calculated by using the Euclidean distance coefficient) on the biotic ordination (Clarke and Gorley 2006). The 
following variables were used in the analyses: depth, sigma-t vertical $(10-50 \mathrm{~m})$ gradient, surface oxygen concentration, depth-integrated $(0-80 \mathrm{~m})$ total chlorophyll- $a$, contribution $(\%)$ of $>5 \mu \mathrm{m}$ sizefractionated chlorophyll- $a$. All variables except depth and contribution (\%) of $>5 \mu \mathrm{m}$ sizefractionated chlorophyll- $a$ had previously been transformed by $\log (x+1)$, and all of them had been standardized before running the BIO-ENV test.

Within the analysis, rank correlation $(\rho)$ of the matching elements was carried out with combinations of environmental variables. A value of $\rho=0$ indicates an absence of any match between the two patterns, where $\rho=+1$ is a perfect match (Clarke and Ainsworth 1993).

\section{Results}

Oceanographic conditions

Temperature-Salinity scatter plots of the recordings made at the 14 CTD stations in the Antarctic Peninsula (AP), Marguerite Bay (MB), Bellingshausen Sea (BS) and Peter I Island (PI) in JanuaryFebruary 2006, are shown in Fig. 2. Surface waters were occupied by the Antarctic surface water (ASW), with temperatures ranging from $\sim-1.8$ to $3.5{ }^{\circ} \mathrm{C}$ and salinities of $\sim 31.7-33.7$ at potential density anomaly $\left(\sigma_{\theta}\right)$ values <27.2. The wide scatter in ASW properties reflects temporal changes in surface waters due to seasonal heating and cooling during the summer and autumn. The minimum temperature $\left(-1.6\right.$ to $\left.-1.7^{\circ} \mathrm{C}\right)$ at salinity values of $\sim 34.1$ was associated with the winter water (WW) produced during the previous winter. Beneath the ASW and the WW, the warmer $\left(1.0-2.0{ }^{\circ} \mathrm{C}\right)$ and more saline (34.5-34.7) water mass that occupies most of the deep layers of the Antarctic Circumpolar Current (ACC) is the Circumpolar Deep Water (CDW), which constitutes the main source of ocean heat and nutrients in the Southern Ocean. The deepest water in the slope is the local Bottom Water (BW) with temperatures ranging from 0 to $0.5^{\circ} \mathrm{C}$ and salinities from 34.6 to 34.7 .

The shallower stations ( $<350 \mathrm{~m}$ ) in the AP (41 and 43) and the MB (39) were only influenced by the ASW. The AP stations were characterized by a weak vertical density gradient $(0.49 \pm 0.06)$ in the surface waters $(10-50 \mathrm{~m}$ ) (see Table 1; Fig. 3). Phytoplankton biomass was relatively low $\left(87 \pm 41 \mathrm{mg}\right.$ chla $\left.\mathrm{m}^{-2}\right)$, and the contribution of large $(>5 \mu \mathrm{m})$ size-class phytoplankton to total chlorophyll- $a$ was $<45 \%$ (Fig. 4). Net Community Production (NCP) rate measured at station 41 was relatively low $\left(63 \mathrm{mmolO}_{2} \mathrm{~m}^{-2} \mathrm{~d}^{-1}\right)$, indicating that in this region, a small amount of organic matter is available for exportation, either to deeper layers or to higher trophic levels.

Station 39, further south in the shallow $(<200 \mathrm{~m})$ waters of the MB, exhibited the maximum vertical density gradient (1.1) in the surface waters. Surface oxygen concentration $\left(408 \mu \mathrm{molO}_{2} \mathrm{~kg}^{-1}\right)$ and phytoplankton biomass ( $375 \mathrm{mg} \operatorname{chl} a \mathrm{~m}^{-2}$ ) were also higher at this station, where the contribution of large $(>5 \mu \mathrm{m})$ size-class phytoplankton to total chlorophyll-awas $>90 \%$. Unfortunately, no NCP experiments were conducted at this station.

The two stations (27 and 28) close to Peter I Island (PI) sampled deeper than 1,000 $\mathrm{m}$ showed the highest contribution of the CDW. The PI stations were characterized by a relatively weak vertical density gradient $(0.4 \pm 0.2)$ and relatively high values of surface oxygen concentration (398 $\left.\pm 2 \mu \mathrm{molO}_{2} \mathrm{~kg}^{-1}\right)$. Phytoplankton biomass was also relatively high $\left(154 \pm 65 \mathrm{mg} \operatorname{chl} a \mathrm{~m}^{-2}\right)$, and the $>5 \mu \mathrm{m}$ size-class phytoplankton predominated, representing more than $90 \%$ of the total chlorophyll- $a$. Maximal NCP rates $\left(304 \pm 116 \mathrm{mmolO}_{2} \mathrm{~m}^{-2} \mathrm{~d}^{-1}\right)$ were measured at these two stations. 
Nine other stations were investigated in the Bellingshausen Sea (BS) from the shelf-break $(<500 \mathrm{~m}$ depth) to deeper waters $(>3,000 \mathrm{~m})$. Most of the stations were in the central part of the BS, whereas station 26 was further west, very close to the Amundsen Sea. These stations showed a high contribution of the WW, and the deeper stations were also influenced by the BW. Only station 29 was influenced by the CDW, probably because of its proximity to the PI. The vertical surface density gradient $(0.74 \pm 0.22)$ was higher than that at the PI stations, whereas surface oxygen concentration

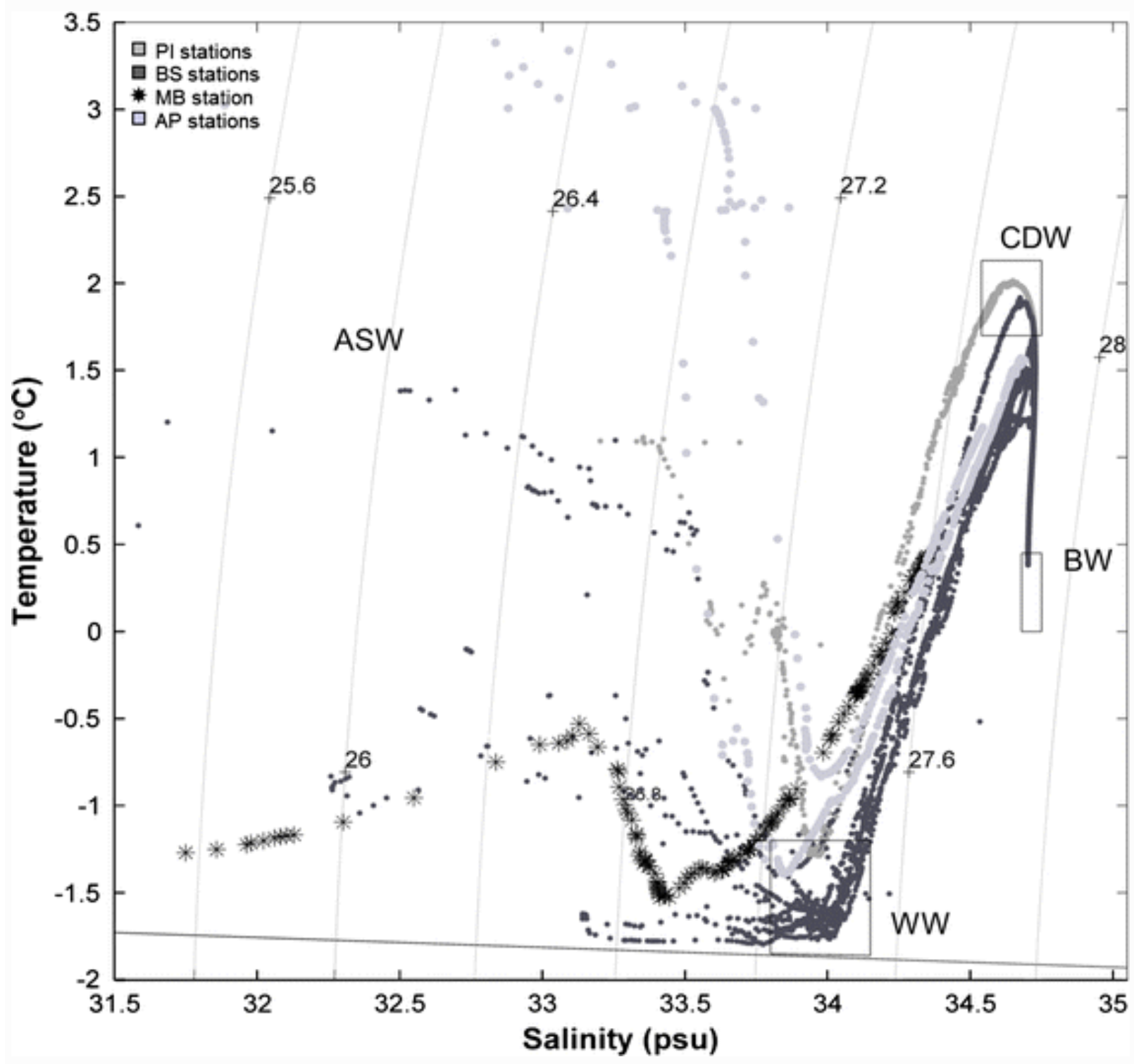

Fig. 2 Temperature-Salinity scatter plot for 14 CTD stations in the Antarctic Peninsula (AP, black), Marguerite Bay (MB, black stars), the Bellingshausen Sea (BS, grey) and Peter I Island (PI, dark grey), in JanuaryFebruary 2006. Key water masses are indicated and labelled following Martinson et al. (2008) $(\mathrm{CDW}=$ Circumpolar Deep Water; WW = Winter Water; ASW = Antarctic Surface Water and BW = Bottom Water). Theblack line indicates the freezing point of seawater. The potential density is indicated bydashed lines. The potential density $\left(\rho_{\theta}\right)$ of a fluid parcel at pressure $P$ is the density that the parcel would acquire if adiabatically brought to a reference pressure $P_{0}$, often $1 \mathrm{bar}(100 \mathrm{kPa}) . \rho_{\theta}$ is especially useful because it is a conserved thermodynamic property. Whereas density changes with changing pressure, the potential density of a fluid parcel is conserved as the pressure experienced by the parcel changes. To avoid difficulties in working with absolute density, density relative to density of pure water is used. For simplification, the last 2 digits of the density are often quoted, a quantity named density anomaly or $\sigma$. The corresponding potential density anomaly is denoted by $\sigma \theta=\rho_{\theta}-1,000 \mathrm{~kg} \mathrm{~m}^{-3}$ 
was lower $\left(354 \pm 33 \mu \mathrm{molO}_{2} \mathrm{~kg}^{-1}\right)$. Similar to the AP stations, phytoplankton biomass $(74 \pm 30 \mathrm{mg}$ chl $\left.a \mathrm{~m}^{-2}\right)$, the contribution of large $(>5 \mu \mathrm{m})$ size-class phytoplankton to total chlorophyll$a(65 \pm 12 \%)$ and NCP rates $\left(68 \pm 31 \mathrm{mmolO}_{2} \mathrm{~m}^{-2} \mathrm{~d}^{-1}\right)$ were lower than in the stations at PI and the MB. Respiration rates determined from in vitro changes in dissolved oxygen at the fourteen stations sampled during the BENTART-06 cruise $\left(11-66 \mathrm{mmolO}_{2} \mathrm{~m}^{-2} \mathrm{~d}^{-1}, \mathrm{CV}=50 \%\right)$ exhibited lower variability than gross primary production rates $\left(48-452 \mathrm{mmolO}_{2} \mathrm{~m}^{-2} \mathrm{~d}^{-1}, \mathrm{CV}=81 \%\right.$ ) (see Table 1 ).

Larval abundance and distribution

The plankton community was dominated by holozooplankton larvae, which accounted for almost $95 \%$ of the total larval abundance (Fig. 5a). Copepod nauplii $(n=122,569)$ were by far the most abundant taxa, contributing about $96 \%$ of the total holoplanktonic larvae, while juvenile stages of the cosmopolitan planktonic lopadorhynchid polychaete species Pelagobia longicirrata $(n=4,886)$ and Euphausiacea larvae $(n=254)$ represented $4 \%$ of the total larvae of holozooplankton.

Table 1 Summary of oceanographic parameters measured at the stations sampled in the Bellingshausen Sea (BS), the Antarctic Peninsula (AP), Peter I Island (PI) and Marguerite Bay (MB) during the BENTART cruise, in January-February 2006: depth (m), depth-integrated $(0-80 \mathrm{~m})$ total chlorophyll- $a\left(\mathrm{mg} \mathrm{m}^{-2}\right)$, contribution (\%) of large $(>5 \mu \mathrm{m})$ size-fractionated phytoplankton to total chlorophyll- $a$, surface oxygen concentration $\left(\mu \mathrm{molO}_{2} \mathrm{~kg}^{-1}\right)$, Net Community Production (NCP) $\left(\mathrm{mmolO}_{2} \mathrm{~m}^{2} \mathrm{~d}^{-1}\right)$, Gross Primary Production, (GPP) $\left(\mathrm{mmolO}_{2} \mathrm{~m}^{2} \mathrm{~d}^{-1}\right)$, Community Respiration $(R)\left(\mathrm{mmolO}_{2} \mathrm{~m}^{2} \mathrm{~d}^{-1}\right)$ and vertical $(10-50 \mathrm{~m})$ gradient of sigma-t $\left(\mathrm{kg} \mathrm{m}^{-3}\right)$

\begin{tabular}{|c|c|c|c|c|c|c|c|c|c|}
\hline \multicolumn{10}{|l|}{ Zones station } \\
\hline & BS & PI & & & & & BS & & \\
\hline & 26 & 27 & 28 & 29 & 30 & 31 & 32 & 34 & 36 \\
\hline Latitude S & 70.2 & 69.0 & 69.0 & 69.4 & 70.0 & 70.0 & 69.8 & 70.1 & 69.9 \\
\hline Longitude W & 95.0 & 90.4 & 90.3 & 89.4 & 87.5 & 86.3 & 86.5 & 84.9 & 80.4 \\
\hline Depth & 1,875 & 1,892 & 1,079 & 3,325 & 1,799 & 1,432 & 1,849 & 600 & 562 \\
\hline Total chl- $a$ & 48.7 & 200.3 & 108.4 & 107.3 & 24.6 & 57.8 & 57.9 & 112.9 & 98.4 \\
\hline$>5 \mu \mathrm{m}$ chl- $a$ & 53.9 & 93.1 & 92.3 & 77.9 & 62.9 & 70.7 & 69.8 & 78.2 & 42.4 \\
\hline Oxygen & 371.6 & 396.2 & 399.1 & 364.3 & 351.0 & 352.5 & 360.7 & 271.4 & 364.2 \\
\hline $\mathrm{HCP}$ & 28.4 & 222.3 & 385.7 & 105.3 & 47.4 & 70.3 & 77.5 & 96.5 & 10.2 \\
\hline $\mathrm{R}$ & 9.3 & 51.0 & 66.5 & 32.7 & 11.2 & 41.2 & 12.1 & 46.0 & 61.2 \\
\hline GPP & 47.7 & 273.2 & 452.2 & 138.3 & 58.6 & 111.5 & 89.6 & 142.5 & 71.5 \\
\hline D sigma-t & 0.74 & 0.51 & 0.26 & 0.69 & 0.52 & 1.05 & 0.91 & 0.44 & 0.71 \\
\hline
\end{tabular}

\begin{tabular}{|c|c|c|c|c|c|c|c|c|c|}
\hline \multirow[t]{2}{*}{ Zones station } & \multicolumn{2}{|l|}{ BS } & \multirow{2}{*}{$\begin{array}{l}\text { MB } \\
39\end{array}$} & \multicolumn{2}{|l|}{$\mathbf{A P}$} & \multicolumn{4}{|c|}{ Mean values zone } \\
\hline & 37 & 38 & & 41 & 43 & PI $(n=2)$ & BS $(n=9)$ & MB & $\mathbf{A P}(n=2)$ \\
\hline Latitude S & 69.4 & 69.2 & 68.1 & 65.5 & 63.4 & & & & \\
\hline Longitude W & 80.9 & 80.0 & 69.6 & 69.0 & 64.3 & & & & \\
\hline Depth & 515 & 1,326 & 162 & 346 & 261 & $1,079-1,892$ & $3,325-432$ & 162 & $261-346$ \\
\hline Total chl-a & 70.6 & 86.0 & 375.3 & 57.9 & 116.5 & $154.3 \pm 65$ & $73.8 \pm 29.5$ & 375.3 & $87.2 \pm 41.3$ \\
\hline$>5 \mu \mathrm{m}$ chl-a & 70.6 & 57.9 & 93.7 & 41.9 & n.d. & $92.7 \pm 0.6$ & $64.9 \pm 118$ & 93.7 & $41.9 \pm$ \\
\hline Oxygen & 385.0 & 366.8 & 407.5 & n.d. & n.d. & $397.7 \pm 2$ & $354.1 \pm 32.6$ & 407.5 & n.d. \\
\hline $\mathrm{HCP}$ & 50.9 & 82.8 & n.d. & 63.0 & n.d. & $304.0 \pm 15.6$ & $63.3 \pm 316$ & n.d. & $63.0 \pm$ \\
\hline $\mathrm{R}$ & 41.0 & 50.2 & n.d. & 19 & n.d. & $58.7 \pm 11$ & $35.0 \pm 172$ & n.d. & $19 \pm$ \\
\hline GPP & 92.0 & 133.0 & n.d. & 82 & n.d. & $362.7 \pm 26.5$ & $98.3 \pm 352$ & n.d. & $82 \pm$ \\
\hline D sigma-t & n.d. & 0.84 & 1.08 & 0.53 & 0.44 & $0.39 \pm 0.18$ & $0.74 \pm 0.2$ & 1.08 & $0.49 \pm 0.06$ \\
\hline
\end{tabular}

Errors represent standard deviations. $n d$ no data are available, $n$ number of stations used to compute the mean values 
A total of 7,122 benthic invertebrate larvae belonging to 15 larval types were collected in this study (Fig. 5b). Molluscan veligers predominated, comprising $90 \%(n=6,432)$ of the total meroplanktonic larvae, with three different larval types present: bivalve veligers $(0.04 \%, n=3)$, echinospira veligers $(61 \%, n=4,333)$ and nudibranch veligers $(29 \%, n=2,096)$, followed by polychaete larvae (mainly nectochaetes) $4 \%(n=293)$, planula larvae (probably from octocorals and sponges) $3 \%(n=211)$ and nemertean larvae, both pilidia and advanced pilidia, $1.25 \%(n=98)$. Other larvae such as ophiopluteus larvae $(n=43)$, echinopluteus larvae $(n=15)$, brachiolaria larvae $(n=3)$, cirripede nauplii $(n=5)$, sipunculid pelagosphaerae $(n=18)$ and ascidian larvae $(n=4)$ were substantially less abundant, representing less than $1 \%$ (Fig. 5b).
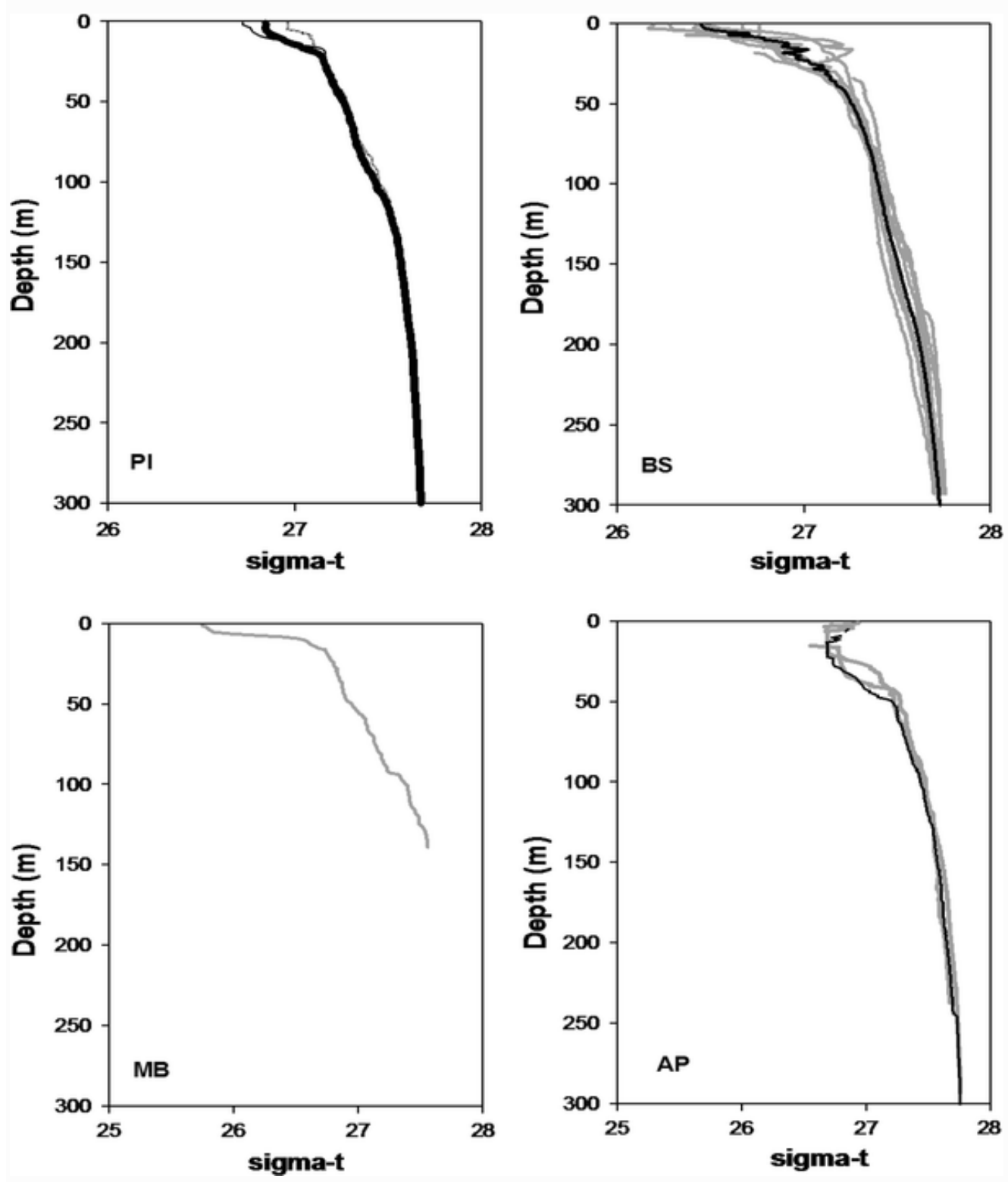

Fig. 3 Vertical profiles of density anomaly (sigma-t) for the stations sampled in the Antarctic Peninsula (AP), Marguerite Bay (MB), the Bellingshausen Sea (BS) and Peter I Island (PI), in January-February 2006. Sigma$t$ is the density anomaly of a water sample when the total pressure on it has been reduced to atmospheric pressure (i.e. zero water pressure), and temperature and salinity correspond to in situ values. Thick dark line represents the averaged profile for all stations sampled in each region 
Coinciding with the increased phytoplankton biomass, the total larval abundance was generally higher close to the shore, near Peter I Island (stations 27 and 28), in Marguerite Bay (station 39), and the Antarctic Peninsula (station 43). The total larval abundance was maximal at MB and decreased in the central part of the Bellingshausen Sea (Figs. 6,7). Copepod nauplii predominated at all stations and were uniformly distributed across the BS, reaching maximal density at PI (894 larvae $\mathrm{m}^{-3}$, station 28) and at MB (974 larvae $\mathrm{m}^{-3}$, station 39) (Fig. 6a). P. longicirrata juveniles were found at all stations, and were most abundant at MB (95 larvae $\mathrm{m}^{-3}$ ) (Fig. 6b). The density of Euphausiacea larvae (namely Euphausia crystallorophias,Euphausia superba and Thyssanoessa macrura), mainly furcilia stages, ranged from 0 to 13 larvae $\mathrm{m}^{-3}$ (Fig. 6c). Calyptopis stages, mainly of $E$. crystallorophias, were only recorded at the coastal stations. The highest densities were also sampled near the shore stations, specifically in MB where euphausiid metanauplii were also encountered (Fig. 6c).

Molluscan larvae were represented by three types of larvae. Echinospira and nudibranch veligers were present at all stations (Fig. 7a, b), whereas bivalve veligers were very rare, appearing only in the central part of the BS (data not shown). Echinospira and nudibranch veligers showed different distribution patterns. Nudibranch veligers mainly occupied the central part of the BS, reaching maximum densities of 24 larvae $\mathrm{m}^{-3}$, whereas echinospira veligers generally predominated close to the shore, reaching the highest density in the AP (65 larvae $\mathrm{m}^{-3}$, station 43) (Fig. 7a, b).
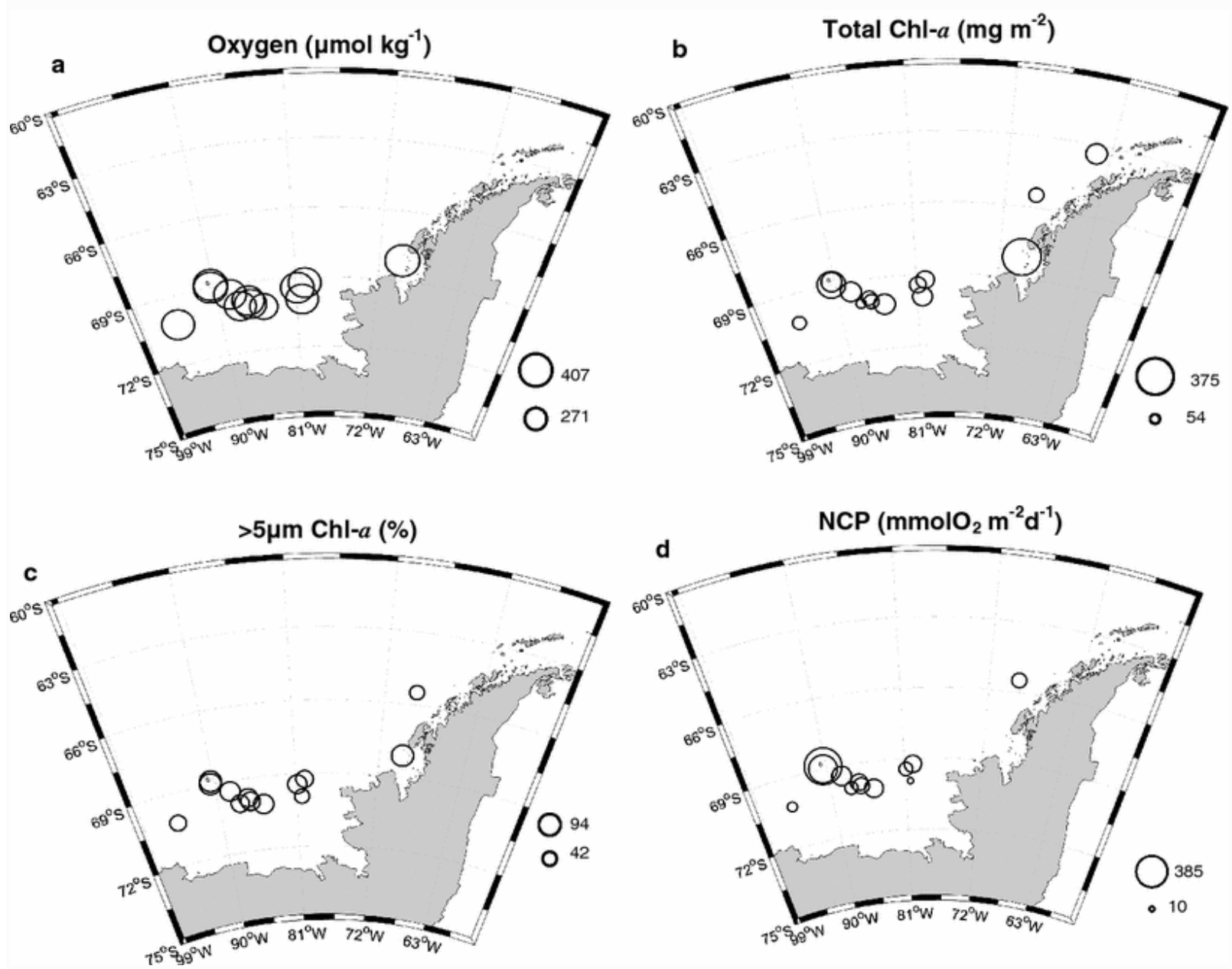

Fig. 4 Distribution of a surface oxygen concentration, b depth-integrated $(0-80 \mathrm{~m})$ total chlorophyll$a$, c contribution $(\%)$ of large $(>5 \mu \mathrm{m})$ size-fractionated phytoplankton to total chlorophyll- $a$ and $\mathbf{d}$ Net Community Production (NCP) in the Bellingshausen Sea during January-February 2006 
Although the larvae of other benthic organisms were much less abundant, their distribution was fairly distinctive (Fig. 7c-h). Polychaete larvae mainly occurred at the near shore stations, exhibiting the highest abundances in MB (9 larvae $\mathrm{m}^{-3}$, station 39) and the PI (5 larvae $\mathrm{m}^{-3}$, station 28), whereas planula larvae, nemertean pilidia and echinoderm larvae, mostly ophioplutei, prevailed in the central part of the BS (Fig. 7c-g).

Advanced nemertean pilidia were very rare throughout the BS, and the highest abundance was sampled in MB (Fig. 7f). Sipunculid pelagosphaerae larvae were found in low numbers mainly close to the coast (Fig. 7h). The four ascidian larvae found during this survey were also collected in MB (data not shown).
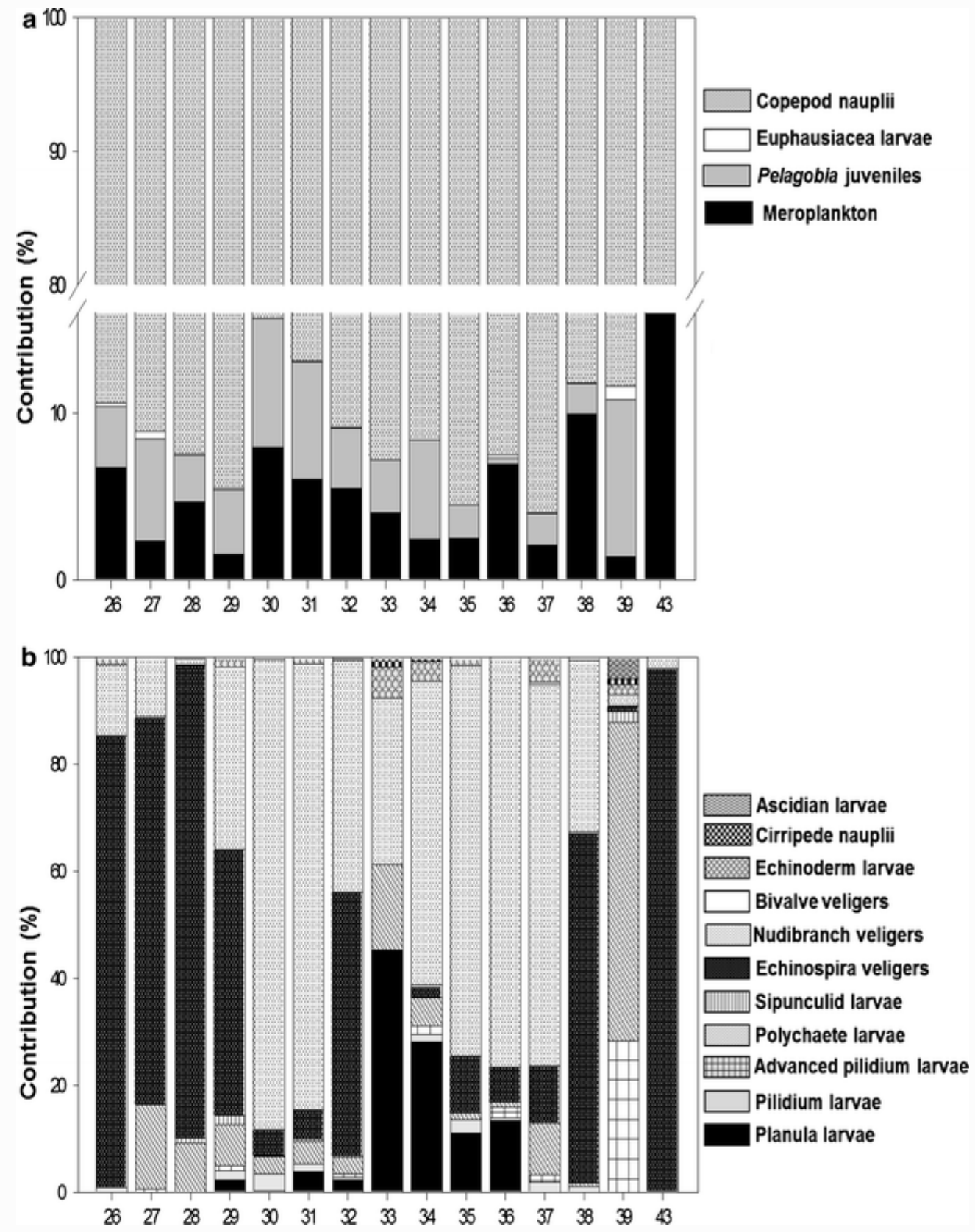

Fig. 5 Contribution (\%) of holoplanktonic (a) and meroplanktonic groups (b) to the total abundance of larvae sampled in the upper $200 \mathrm{~m}$ at the stations investigated in the Bellingshausen Sea during January-February 2006. Total larvae abundance for holoplanktonic and meroplanktonic groups is represented in Figs. 6 and 7. Echinoderm larvae include three larval types: ophioplutei, echinoplutei and brachiolaria 


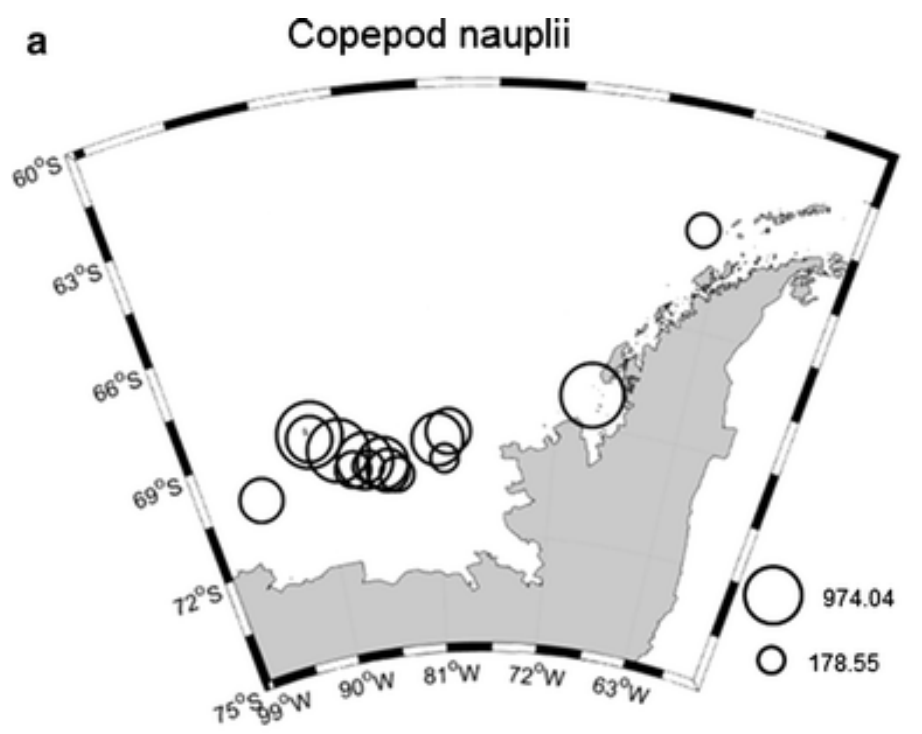

Fig. 6 Abundance (larvae $\mathrm{m}^{-3}$ ) of holoplanktonic larval groups in the upper $200 \mathrm{~m}$ sampled in the Bellingshausen Sea in January and February 2006. Euphausiacea larvae were represented according to their developmental stages
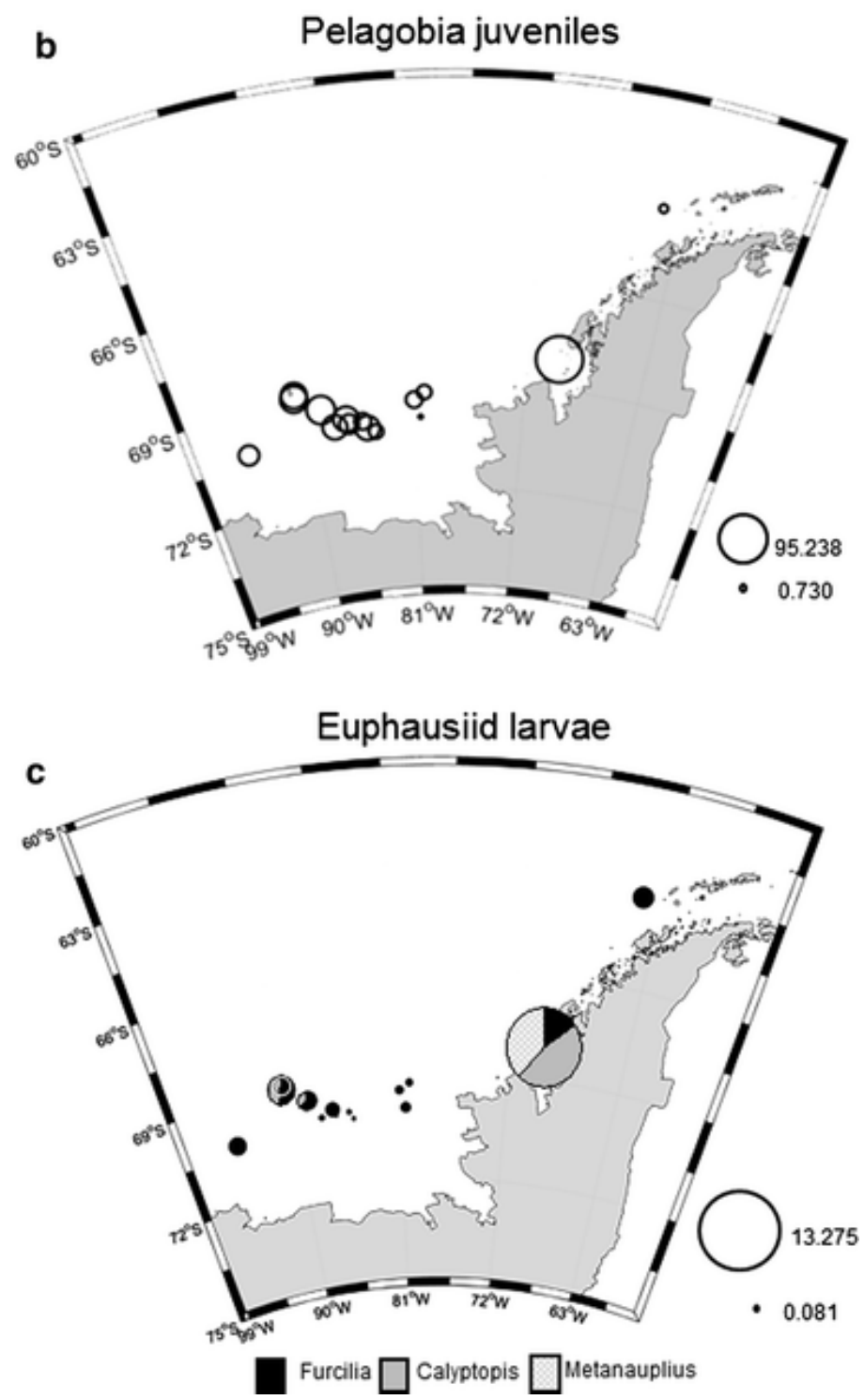

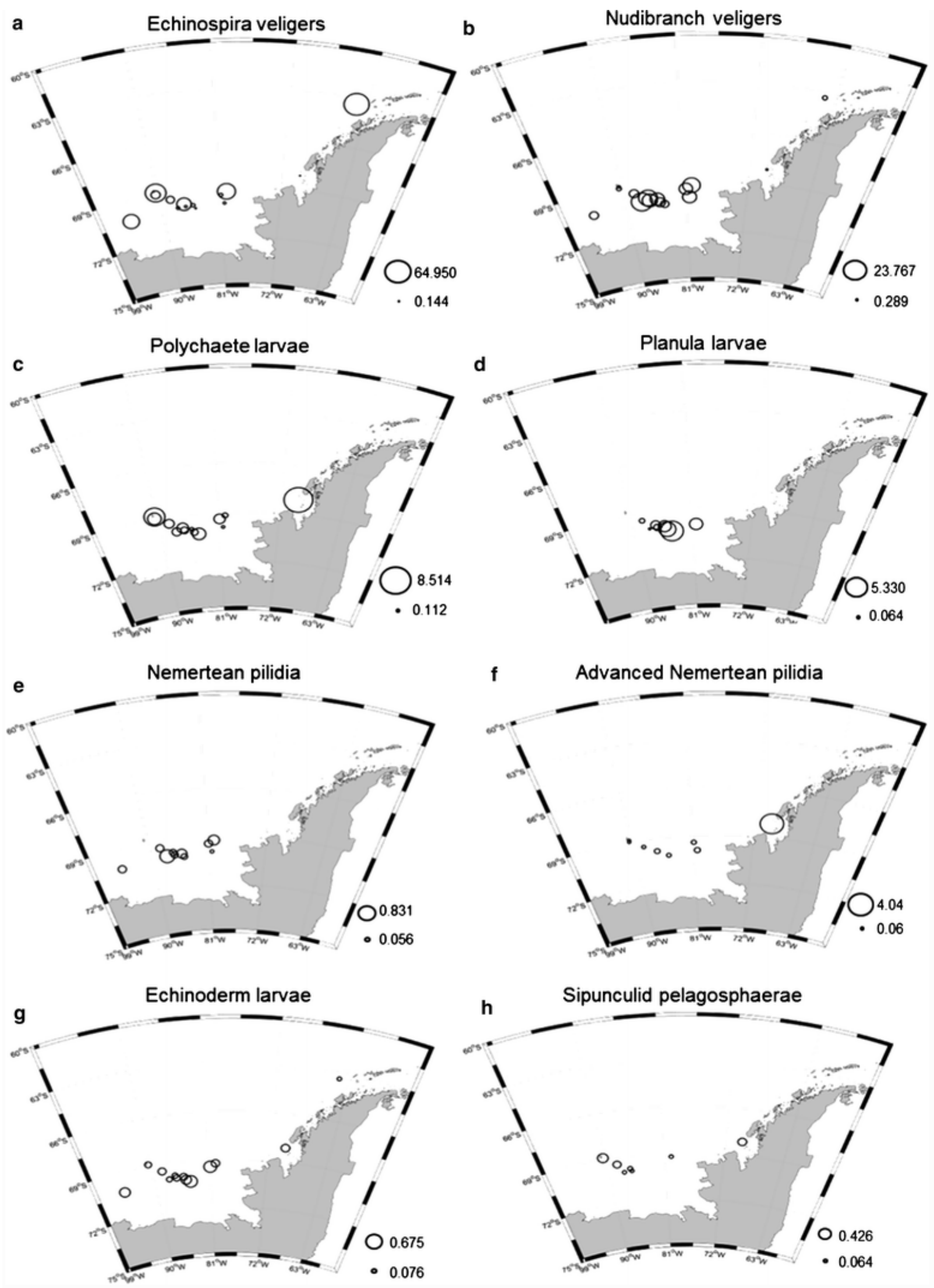

Fig. 7 Abundance (larvae $\mathrm{m}^{-3}$ ) of meroplanktonic larval groups in the upper $200 \mathrm{~m}$ sampled in the Bellingshausen Sea in January and February 2006 
Cluster analysis of the abundance of meroplankton revealed two major groups with a level of similarity of about $60 \%$ (Fig. 8a). Group I included those stations characterized by a higher abundance of echinospira veliger larvae: two stations at PI (27 and 28), two stations in the BS (stations 26 and 38), as well as station 43 in the AP. Group II incorporated the other stations sampled in the BS, characterized by higher abundances of nudibranch veligers and also a large proportion of planula, nemertean pilidia and echinoderm larvae. Finally, station 39 in the MB was different from the others on account of the lack of gastropod larvae and the high abundance of different types of larvae such as polychaete nectochaetes, advanced nemertean pilidia and ascidian larvae.

The MDS ordination plot (Fig. 8b) showed similar results to those of the dendrogram, with an acceptable stress value (0.12). The sampling sites were segregated according to the larval abundance gradient, coinciding with coastal stations and the increased phytoplankton biomass.

The results of the BIO-ENV analyses (Table 2) indicated a relatively good fit between environmental variables and the larval data matrix. The highest correlation $(\rho=0.583)$ was between a combination of total chlorophyll- $a$ and the contribution of large $(>5 \mu \mathrm{m})$ phytoplankton to total chlorophyll- $a$, suggesting that food availability constitutes an important factor determining larval abundance. However, we cannot disregard the possibility that larval abundance and composition may also be at least partly affected, by water circulation patterns that influence the distribution of drifters. When each variable was considered separately, the contribution of large phytoplankton to the total chlorophyll- $a$ was the variable mostly closely correlated $(\rho=0.560)$ with meroplanktonic abundance and composition.
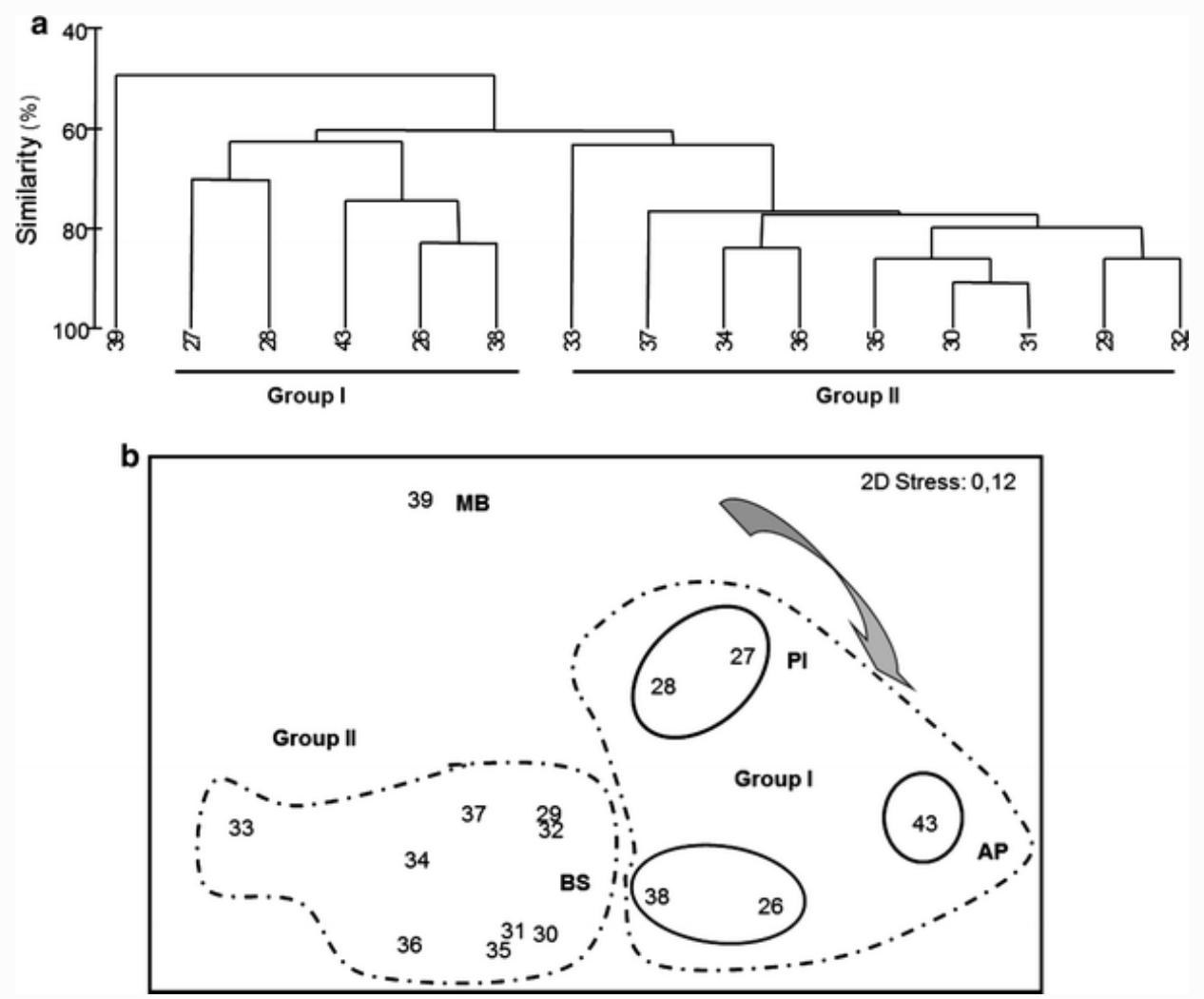

Fig. 8 Hierarchical cluster analysis (a) based on the Bray-Curtis similarity coefficient on the basis of the abundance of the meroplanktonic larval groups sampled from the upper $200 \mathrm{~m}$, at each station.MDS ordination analysis (b) on the basis of the abundance of the meroplanktonic larval groups sampled from the upper $200 \mathrm{~m}$, at each station. Dashed circles show major assemblages according to the hierarchical cluster analysis. The black arrow represents the decreasing larval abundance from coastal stations, Marguerite Bay (MB), Peter I Island (PI), and Antarctic Peninsula (AP) to the central part of the Bellingshausen Sea (BS) 


\section{Discussion}

Phytoplankton biomass is low throughout most of the Southern Ocean, and enhanced concentrations are mainly associated with coastal sea ice edge and frontal system zones (Comiso et al. 1993; Boyd et al. 1995). Because of the intense mixing and the effect of irradiance and iron limitation, no sustained blooms occur in deeper waters (Smith and Comiso 2008). The generation of a stratified surface layer where ice melts can stimulate growth of phytoplankton and accumulation of phytoplankton biomass (Smith and Nelson 1985). The BS, characterized by moderate concentration of surface chlorophyll $\left(0.1-1 \mathrm{mg} \mathrm{m}^{-3}\right.$ ) (Comiso et al. 1993), is affected by the north-eastward flowing Antarctic Circumpolar Current (ACC), with its southern boundary located on the upper continental slope along the 750-1,000 m isobath (Hofmann and Klinck 1998). The presence of the ACC along the continental shelf is responsible for the subsurface on-shelf intrusions of the Circumpolar Deep Water (CDW) (Dinniman and Klinck2004), which influence the thermohaline properties, as well as nutrient and phytoplankton distributions (Klinck 1998; Prezelin et al. 2000).

A large degree of variability in phytoplankton biomass and production was observed in the BS in January-February 2006, during the BENTART-06 cruise. Higher chlorophyll- $a$, NCP rates and contribution of large phytoplankton were found at the stations at PI and in the MB (see Table 1; Fig. 4). T-S diagrams indicated that the PI stations were under the influence of CDW intrusions, whereas station 39 sampled close to the ice shelf in the MB was characterized by stratified surface

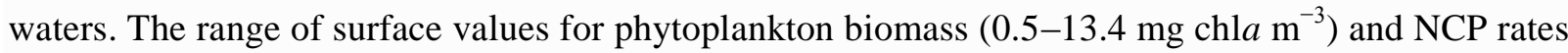
$\left(0.1-9.2 \mathrm{mmolO}_{2} \mathrm{~m}^{-3} \mathrm{~d}^{-1}\right)$ reported during the BENTART-06 cruise were consistent with the findings of previous studies carried out in the region (see Table 2 in Agustí et al. 2004). The classic view of the Southern Ocean proposed a short food chain supported by diatom growth (Hart 1942). However, later studies indicated that nano- and picoplankton ( $<20$ and $<2 \mu \mathrm{m}$, respectively) are important components of the Antarctic phytoplanktonic community, with large diatoms being abundant in coastal and restricted environments and associated with fronts (Ducklow et al. 2007).

In the study area, the holoplankton dominated over the meroplankton community. Holozooplankton larvae were found at all the stations, but were more abundant at stations where phytoplankton biomass was highest. In agreement with these results, Burkill et al. (1995) and Weeks et al. (1995)

Table 2 Results of the BIO ENV analysis conducted to select the number of oceanographic parameters that best match the biotic matrix according to the values of the Spearman's rank correlation $(\rho)$

\begin{tabular}{lll}
\hline Number of variables & Correlation & Selections \\
\hline 2 & $\mathbf{0 . 5 8 3}$ & 2,3 \\
1 & 0.560 & 3 \\
3 & 0.535 & $2,3,5$ \\
3 & 0.513 & $2-4$ \\
4 & 0.488 & $2-5$ \\
1 & 0.453 & 2 \\
4 & 0.452 & $1-3,5$ \\
3 & 0.428 & $1-3$ \\
2 & 0.419 & 3,4 \\
5 & 0.418 & All
\end{tabular}

The values in bold type provide the best match. The numbers correspond to: 1 depth; 2 depth-integrated total chlorophyll- $a, 3$ contribution $(\%)$ of large $(>5 \mu \mathrm{m})$ size-fractionated phytoplankton to total chlorophyll$a, 4$ surface oxygen concentration, and 5 vertical (10-50 m) gradient of sigma-t 
found that macrozooplankton and microzooplanton, as well as micronekton, were closely associated with increased phytoplankton biomass.

Copepod nauplii dominated the sampled area, probably because of the high abundance of several copepod species, mainly Calanoides acutus, Rhincalanus gigas, Oithona spp. andMetridia gerlache, previously registered in this area (Atkinson and Shreeve 1995). Similar results with regard to the dominance of copepod nauplii were recorded in other Antarctic areas, especially during the summer [Vázquez et al. (2007) in the Bransfield Strait; Elliott et al. (2008) in the McMurdo Sound].

Juveniles of $P$. longicirrata were also very abundant during the survey, representing almost $85 \%$ of the total polychaete larvae. Comparable estimates of the abundance of $P$. longicirratahave been reported for other Antarctic areas (Kittel et al. 2001; Freire et al. 2006). The highest density registered in the MB (station 39) was probably due to the enhanced phytoplankton biomass measured at this station, since $P$. longicirrata has an exclusive diet of phytoplankton (Hopkins and Torres 1989). In contrast to previous reports for the Antarctic Peninsula region during the austral summer (Makarov et al. 1990; Pakhomov et al. 2004), the scarcity of krill larvae may be attributed to the sampling procedure, since larval euphausiids can avoid the net used in this study (Brinton 1967; Mathew 1988; Marschoff et al. 1998). Furcilia stages were dominant across the BS, although metanauplius and calyptopis stages of E. superba and E. crystallorophias were found at PI and in the MB. The lack of metanauplius and calyptopis stages of T. macrura may be the result of different reproductive strategies, since $T$. macruraspawns in September (Makarov 1979), E. crystallorophias spawns between late November and January, followed by E. superba, which mainly spawns between December and March (Hosie1991; Kirkwood 1996; Taki et al. 2009; Marrari et al. 2011).

As observed for Pelagobia, euphausiid larvae mainly appeared at those stations close to the shore, characterized by enhanced phytoplankton biomass. This is consistent with the findings of Ducklow et al. (2007), who reported the presence of adult populations near coastal areas associated with high phytoplankton concentrations, suggesting that larvae do not move away from the spawning areas during development (Miquel 1991).

The abundance of meroplankton across the Bellingshausen Sea varied from 10.67 (St34, in the BS) to 66.36 larvae $\mathrm{m}^{-3}$ (in the AP). Although quantitative comparison of larval numbers is difficult because of differences in sampling gear, depth sampling and plankton mesh size, the present data are within the range reported in previous studies in the Antarctic. Shreeve and Peck (1995) reported an abundance of about 20 larvae $\mathrm{m}^{-3}$ in the Bellingshausen Sea in November-December. Freire et al. (2006) described densities of 11-21 larvae $\mathrm{m}^{-3}$ for King George Island in 2000-2001, Bowden et al. (2009) reported mean monthly densities of 54.4 larvae $\mathrm{m}^{-3}$ at Rothera (south-eastern Adelaide Island), and Sewell and Jury (2011) reported a total abundance of 59.01 larvae $\mathrm{m}^{-3}$ at Ross Island in summer. These values are one order of magnitude higher than those described for Signy Island (2.74 larvae $\mathrm{m}^{-3}$, Stanwell-Smith et al.1999), King George Island [0.83-1.6 larvae $\mathrm{m}^{-3}$, Freire et al. (2006) for 2000-2001] and the Bransfield Strait (5 larvae $\mathrm{m}^{-3}$, Vázquez et al. 2007). A remarkably high abundance of 228 larvae $\mathrm{m}^{-3}$ was observed by Tanimura et al. (1986) for the Syowa station in the eastern Antarctica.

Except for the latter value, larval abundances reported in the Antarctic are generally lower than those reported for temperate [280 larvae $\mathrm{m}^{-3}$ in the Swedish coast of Oresund (Thorson 1950), 3,000 larvae $\mathrm{m}^{-3}$ in the North Sea (Bosselmann 1989)] and tropical waters [120,000 larvae $\mathrm{m}^{-3}$ in the SE India 
(Srikrishnadhas et al. 1993)]. In fact, much lower numbers were observed in Long Island Bay (1-3 individuals $\mathrm{m}^{-3}$ ) (Cook and Jones 1980) and in East Greenland (84 larvae $\mathrm{m}^{-3}$ ) (Clough et al. 1997).

However, the scarcity of benthic marine invertebrate larvae in the Southern Ocean has been related to abundance rather than to larval type richness (Stanwell-Smith et al. 1999; Bowden et al. 2009; Sewell and Jury 2011). Nevertheless, larval diversity may be overestimated or underestimated since it depends on a number of author-specific criteria (Sewell and Jury 2011), and therefore improved molecular techniques are required for identifying marine invertebrate larvae (Sewell and Jury 2011) and for a better understanding of bentho-pelagic coupling and the recruitment process.

The meroplankton community in the Bellingshausen Sea was dominated by gastropod larvae, in contrast to reports by Shreeve and Peck (1995) who found a lower abundance of gastropod larvae, except at the outer open water station, pointing out that these larvae may be swept offshore by currents or may be produced by deep-water or holoplanktonic species. This appears likely since the gastropod adults that reproduce via pelagic larvae are not very abundant in the BS (Troncoso et al. 2007; Sáiz et al. 2008). Troncoso et al. (2007) observed mainly bivalve in the benthos, but the presence of bivalve veligers in the samples was anecdotal, which may indicate that the larvae live demersally (Hain and Arnaud 1992).

The multivariate analysis, according to the relative contribution of the dominant taxa and the variety of larval types, showed that there were differences in the meroplankton composition and abundance, which were correlated with phytoplankton biomass. Two main meroplanktonic assemblages were discriminated by this analysis. The GI cluster included stations predominated by echinospira veligers and polychaete larvae. The abundance and distribution of gastropod veligers may be related to a peak in primary production at the end of the January and February (Absher et al. 2003; Freire et al. 2006). In other Antarctic areas, polychaete larvae also coincide with the summer bloom [in Ross Sea, Pane et al. (2004), in Admiralty Bay, Freire et al. (2006); in Rothera Bay, Bowden et al. (2009)].

Stations in the central part of the BS (cluster GII) were characterized by the predominance of nudibranch veligers, which were probably larval stages of Cephalaspidae (J. Troncoso, personnel communication), and higher abundances of other larval types such as nemertean pilidia, echinoderm larvae and planula larvae. This distribution may be related to the proximity to the pack ice (see Fig. 1), as nudibranch veligers and nemertean pilidia have often been reported to occur close to or in the pack ice (Sewell 2006; Sewell et al. 2006; Freire et al. 2006). Shreeve and Peck (1995) reported higher abundances of nemertean and echinoderm larvae close to the continental shelf, which decreased offshore. On the shelf, both nemertean pilidia and echinoderm larvae would benefit from the higher abundance of nano- and picophytoplankton (Boyd et al. 1995), which can be ingested by these larvae (Peck 1993). On the other hand, the higher abundance of planula larvae may be due to the presence of adult taxa in the area (Gutt 2007).

Finally, station 39 sampled in the MB was distinguished from the other stations by the lack of gastropod larvae, probably due to the scarcity of adult gastropods in the Rothera area (south-eastern Adelaide Island) reproducing via pelagic larvae (Bowden et al. 2009). A high abundance of other larval types such as polychaetes, advanced nemertean pilidia and ascidian larvae may occur as a result of the high abundance of benthic fauna in the area (Raguá-Gil et al. 2004; Saiz et al. 2008; Parapar et al. 2011), since the geomorphology of the bay and the presence of small gyres may contribute to larval retention (Ashjian et al. 2004). The higher abundance of advanced nemertean pilidia may be related to the peak abundance of nemertean juveniles recorded by Bowden et al. (2009) at Rothera, which may indicate the beginning of metamorphosis and settlement of nemerteans 
coincide with the onset of phytoplankton bloom. The lower presence of echinoderm and ascidian larvae than reported by Bowden et al. (2009) may be due to the fact that these types of larvae mainly occur in winter and early summer in this area (Bowden et al. 2009).

The composition of the meroplanktonic community observed during this survey was generally similar to that reported in previous studies carried out in the Ross Sea (Sewell 2005) and Admiralty Bay (Freire et al. 2006) and off Signy Island (Stanwell-Smith et al. 1999), that is, a predominance of molluscan veligers and nectochaete polychaetes. By contrast, Shreeve and Peck (1995) described a predominance of nemertean pilidia and ophiopluteus in the Bellingshausen Sea during the early summer of 1992. This may be related to the use of the large mesh plankton net $(200 \mu \mathrm{m})$, which may not collect the smaller forms (echinospira and nudibranch veligers). On the other hand, the higher diversity of larval types may be explained by the different reproductive strategies of benthic invertebrates, as some of the most abundant species in these cold-water habitats reproduce seasonally, coinciding with the phytoplankton bloom (Kirkwood 1996; Stanwell-Smith et al. 1999; Bowden et al. 2009; Sewell and Jury 2011), so that the timing of sampling is important. Thus, the lower presence of nemertean pilidia in the water column in the present study than that reported by Shreeve and Peck (1995) may be due to the fact that larval settlement had already started in the area, since the nemertean pilidia found in this study are similar to those described by Peck (1993), who studied the reproduction of the Antarctic nemertean Parbolasia corrugatus and found that the developmental period lasted 2 months. Nevertheless, according to Mahon et al. (2010), pilidia of the abundant nemertean $P$. corrugatus are not a large component of the Antarctic meroplankton, representing only $4.3 \%$ of larvae sampled at Antarctic Peninsula, which suggests a mismatch between morphological and molecular identification of larval types.

The present study carried out in Bellingshausen Sea during January and February complements the work of Shreeve and Peck (1995) carried out in November and December, showing a different temporal occurrence of invertebrate larvae. The abundance of phytoplankton and hydrographical conditions may explain the distribution of larvae. Moreover, the diversity of larval types found during this survey reinforces the hypothesis that indirect development plays a key role in benthic recruitment in polar areas, in contrast with the idea proposed in the early nineteenth century (see Pearse and Lockhart 2004), of the predominance of direct development in the life cycle of benthic invertebrates at polar latitudes (Murray 1895; Thorson 1950).

\section{Acknowledgments}

The authors thank A. Ramos, leader of the Spanish BENTART Project, for support for this study during the expedition, and J. Troncoso (Univ. Vigo), F. García (Univ. Pablo de Olavide, Sevilla), $\mathbf{M}^{\mathrm{a}}$ Eugenia Manjón (Univ. Malaga), Jordi Corbera, Francina Moya (Instituto Español de Oceanografía, Málaga) and Pilar Ríos for their help in collecting the samples. We extend our thanks to all the scientists participating in the BENTART-06 cruise, officers, crew and UTM technicians of the RV Hespérides for their invaluable help. The authors also thank J. Pearse and another two anonymous reviewers whose comments helped us to improve the final paper. The study is a result of the BENTART Project sponsored by the Spanish Ministry of Science and Technology (CGL2004/01856). J. Ameneiro was in receipt of a grant from the MEC (Project CTM2008-06343$\mathrm{C} 02$ ), and B. Mouriño-Carballido was financially supported by the MICINN-RYC program. 


\section{References}

Absher TM, Boehs G, Feijo AR, da Cruz AC (2003) Pelagic larvae of benthic gastropods from shallow Antarctic waters of Admiralty Bay, King George Island. Polar Biol 26:359-364

Agustí S, Satta MP, Mura MP (2004) Summer community respiration and pelagic metabolism in upper surface Antarctic waters. Aquat Microb Ecol 35:197-205

Arntz WE, Gili JM (2001) A case for tolerance in marine ecology: let us not put out the baby with the bathwater. Sci Mar 65:283-299

Ashjian CJ, Rosenwaks GA, Wiebe PH, Davis CS, Gallager SM, Copley NJ, Lawson GL, Alatalo P (2004) Distribution of zooplankton on the continental shelf oV Marguerite Bay, Antarctic Peninsula, during Austral Fall and Winter 2001. Deep Sea Res II 51:2073-2098

Assmann KM, Timmermann R (2005) Variability of dense water formation in the Ross Sea. Ocean Dynam 55:6887

Atkinson A, Shreeve RS (1995) Response of the copepod community to a spring bloom in the Bellingshausen Sea. Deep Sea Res II 42:1291-1311

Bosselmann A (1989) Larval plankton and recruitment of macrofauna in a subtidal area in the German Bight. In: Ryland JS, Tyler PA (eds) Reproduction, genetics and distributions of marine organisms. Olsen and Olsen, Fredensborg, pp 43-54

Bowden DA, Clarke A, Peck L (2009) Seasonal variation in the diversity and abundance of pelagic larvae of Antarctic marine invertebrates. Mar Biol 156:2033-2047

Boyd PW, Robinson C, Savidge G, Williams PJB (1995) Water column and sea ice primary production during Austral spring in the Bellingshausen Sea. Deep Sea Res II 42:1177-1200

Brinton E (1967) Vertical migration and avoidance capability of euphausiids in the California Current. Limnol Oceanogr 12:451-483

Burkill PH, Edwards ES, Sleigh MA (1995) Microzooplankton and their role in controlling phytoplankton growth in the marginal ice zone of the Bellingshausen Sea. Deep Sea Res II 42:1277-1290

Calbet A, Alcaraz M, Atienza D, Broglio E, Vaqué D (2005) Zooplankton biomass distribution patterns along the western Antarctic Peninsula (December 2002). J Plankton Res 27:1195-1203

Clarke KR, Ainsworth M (1993) A method of linking multi-variate community structure to environmental variables. Mar Ecol Prog Ser 92:205-219

Clarke KR, Gorley RN (2006) PRIMER v6: user manual/tutorial. PRIMER-E, Plymouth, UK

Clarke A, Johnston NM (2003) Antarctic marine benthic diversity Ocean Mar Biol Annu Rev 41:47-114

Clough LH, Ambrose WG Jr, Ashjian CJ, Piepenburg D, Renaud PE (1997) Meroplankton abundance in the Northeast Water Polynya: insight from oceanographic parameters and benthic abundance patterns. J Mar Syst 10:343-357

Comiso JC, McClain CR, Sullivan CW, Ryan JP, Leonard CL (1993) Coastal zone color scanner pigment concentrations in the Southern Ocean and relationships to geophysical surface features. J Geophys Res 98:2419-2451

Cook PH, Jones DA (1980) Preliminary observation on zooplankton Xuctuations in Long Island Bay, Sherkin, SW Ireland. J Sherkin Island 1:69-84

Culberson CH (1994) Dissolved oxygen. In: WOCE Operations manual, vol 3, Section 3.1. Part 3.1.3. WHP. OYce Report. WHPO 91-1 WOCE Report N 68/91 Nov 1994. Revision 1. Woods Hole, MA, USA

Dinniman MS, Klinck JM (2004) A model study of circulation and cross-shelf exchange on the west Antarctic Peninsula continental shelf. Deep Sea Res II 51:2003-2022

Ducklow HW, Baker K, Martinson DG, Quetin LB, Ross RM, Smith RC, Stammerjohn SE, Vernet M, Fraser W (2007) Marine pelagic ecosystems: the West Antarctic Peninsula. Phil Trans R Soc Lond B Biol Sci 362:6794

Elliott DT, Tang KW, Shields AR (2008) Mesozooplankton beneath the summer sea ice in McMurdo Sound, Antarctica: abundance, species composition, and DMSP content. Polar Biol 32:113-122

Freire AS, Absher TM, Cruz-Kaled AC, Kern Y, Elbers KL (2006) Seasonal variation of pelagic invertebrate larvae in the shallow Antarctic waters of Admiralty Bay (King George Island). Polar Biol 29:294-302

Gibbons MJ, Spiridonov VA, Tarling GA (1999) Euphausiacea. In: Boltovskoy D (ed) South Atlantic zooplankton. Backhuys, Leiden, pp 1241-1279 
Gutt J (2007) Antarctic macro-zoobenthic communities: a review and an ecological classiWcation. Antarct Sci 19(2):165-182

Hain S, Arnaud PM (1992) Notes on reproduction of high-Antarctic molluscs from the Weddell Sea. Polar Biol 12:303-312

Hart TJ (1942) Phytoplankton periodicity in Antarctic surface waters. Discov Rep 21:261-347

Hofmann EE, Klinck JM (1998) Hydrography and circulation of the Antarctic continental shelf: 150 E eastward to the Greenwich Meridian. In: Robinson AR, Brink KH (eds) The sea, the global coastal ocean: regional studies and synthesis, vol 11. Wiley, New York, pp 997-1042

Hopkins TL, Torres JJ (1989) Midwater food web in the vicinity of a marginal ice zone in the western Weddell Sea. Deep Sea Res I 36:543-560

Hosie GW (1991) Distribution and abundance of euphausiid larvae in the Prydz Bay region, Antarctica. Antarct Sci 3:167-180

Kaufmann RS, Fisher EC, Gill WH, King AL, Laubacher M, Sullivan B (2003) Temporal patterns in the distribution, biomass and community structure of macrozooplankton and micronekton within Port Foster, Deception Island, Antarctica. Deep Sea Res II 50:1765-1785

Kirkwood JM (1996) The development rate of Euphausia crystallorophias larvae in Ellis Fjord, Vestfold Hills, Antarctica. Polar Biol 16:527-530

Kittel W, Sicinski J, Zmijewska MI, Bielecka L, Blachowiak-Samolyk K (2001) Antarctic neritic zooplankton community (Admiralty Bay, King George Island, South Shetland Islands). Pol Polar Res 22:11-33

Klinck JM (1998) Heat and salt changes on the continental shelf west of the Antarctic Peninsula between January 1993 and January 1994. J Geophys Res 103:7617-7636

Mahon AR, Thornhill DJ, Norenburg JL, Halanych KM (2010) DNA uncovers Antarctic nemertean biodiversity and exposes a decadesold cold case of asymmetric inventory. Polar Biol 33:193-202

Makarov RR (1979) Larval distribution and reproductive ecology of Thysanoessa macrura (Crustacea: Euphausiacea) in the Scotia Sea. Mar Biol 52:377-386

Makarov RR, Menshenina L, Spiridonov V (1990) Distributional ecology of euphausiid larvae in the Antarctic Peninsula region and adjacent waters. Proc NIPR Symp Polar Biol 3:23-35

Marrari M, Daly KL, Timonin A, Semenova T (2011) The zooplankton of Marguerite Bay, Western Antarctic Peninsula - part I: abundance, distribution and population response to variability in environmental conditions. Deep Sea Res II 58:1599-1613

MarschoV ER, Calcagno JA, Amieiro P (1998) Diel variation in catches of Euphausia superba Dana 1854 early larvae: vertical migration or avoidance reaction? J Exp Mar Biol Ecol 228:107-115

Martinson DG, Stammerjohn SE, Iannuzzi RA, Smith RC, Vernet M (2008) Western Antarctic Peninsula physical oceanography and spatio-temporal variability. Deep Sea Res II 55:1964-1987

Mathew KJ (1988) Net avoidance behavior among larval, juvenile and adult euphausiids. J Mar Biol Ass India 30:93-98

Miquel JC (1991) Distribution and abundance of post-larval krill (Euphasia superba Dana) near Prydz Bay in summer with reference to environmental condition. Antarct Sci 3:279-292

Mouriño-Carballido B, McGillicuddy D (2006) Mesoscale variability in the metabolic balance of the Sargasso Sea. Limnol Oceanogr 51:2675-2689

Murray J (1895) General observations on the distribution of marine organisms. Report scientiWc research, voyage of the H.M.S. challenger, a summary of the scientiWc results, second part. pp 1431-1462

Pakhomov EA, Atkinson A, Meyer B, Oettl B, Bathmann U (2004) Daily rations and growth of larval krill Euphausia superba in the Eastern Bellingshausen Sea during austral autumn. Deep Sea Res II 51:2185-2198

Pane L, Feletti M, Francomacaro B, Mariottini GL (2004) Summer coastal zooplankton biomass and copepod community structure near the Italian Terra Nova Base (Terra Nova Bay, Ross Sea, Antarctica). J Plankton Res 26:1479-1488

Parapar J, López E, Gambi MC, Núñez J, Ramos A (2011) Quantitative analysis of soft-bottom polychaetes of the Bellingshausen Sea and Gerlache Strait (Antarctica). Polar Biol 34:715-730

Pearse JS, Bosch I (2002) Photoperiodic regulation of gametogenesis in the Antarctic sea star Odontaster validus Koehler: evidence for a circannual rhythm modulated by light. Invertebr Reprod Dev 41:73-81

Pearse JS, Lockhart SJ (2004) Reproduction in cold water: paradigm changes in the 20th century and a role for cidaroid sea urchins. Deep Sea Res Part II 51:1533-1549 
Pearse JS, McClintock JB, Bosch I (1991) Reproduction of Antarctic benthic marine invertebrates: tempos, modes, and timing. Am Zool 31:65-80

Peck LS (1993) Larval development in the Antarctic nemertean Parbolasia corrugatus (Heteronemertea: Lineida). Mar Biol 116:301-310

Peck LS, Convey P, Barnes DKA (2006) Environmental constraints on life histories in Antarctic ecosystems: tempos, timings and predictability. Biol Rev 81:75-109

Prezelin BB, Hofmann EE, Mengelt C, Klinck JM (2000) The linkage between upper circumpolar deep water (UCDW) and phytoplankton assemblages on the west Antarctic Peninsula continental shelf. J Mar Res 58:165-202

Raguá-Gil JM, Gutt J, Clarke A, Arntz WE (2004) Antarctic shallowwater mega-epibenthos: shaped by circumpolar dispersion or local conditions? Mar Biol 144:829-839

Saiz JI, García FJ, Manjón-Cabeza ME, Parapar J, Peña-Cantero A, Saucède T, Troncoso J, Ramos A (2008) Community structure and spatial distribution of benthic fauna in the Bellinghausen Sea (West Antarctica). Polar Biol 31:735-743

San Vicente C, Munilla T, Corbera J, Sorbe J-C, Ramos A (2009) Suprabenthic fauna from the Bellingshausen Sea and western Antarctic Peninsula; spatial distribution and community structure. Sci Mar 73:357-368

Sewell MA (2005) Examination of the meroplankton community in the south-western Ross Sea, Antarctica, using a collapsible plankton net. Polar Biol 28:119-131

Sewell MA (2006) The meroplankton community of the northern Ross Sea: a preliminary comparison with the McMurdo Sound region. Antarct Sci 18:595-602

Sewell MA, Jury JA (2011) Seasonal patterns in diversity and abundance of the high Antarctic meroplankton: plankton sampling using a Ross Sea desalination plant. Limnol Oceanogr 56:1667-1681

Sewell MA, Lavery S, Baker CS (2006) Whose larva is that? Molecular identiWcation of planktonic larvae of the Ross Sea. New Zealand Aquatic Environment and Biodiversity, Report No 3, pp. 57 Available from http://www.fish.govt.nz/NR/rdonlyres/5612F5DF-5837-4AAA-AD76F3BE85A7C8B0/1572/NZAEBReport3.pdf

Shreeve RS, Peck L (1995) Distribution of pelagic larvae of benthic marine invertebrates in the Bellingshausen Sea. Polar Biol 15:369-374

Smith WO Jr, Comiso JC (2008) InXuence of sea ice on primary production in the southern ocean: a satellite perspective. J Geophys Res 113:C05S93. doi:10.1029/2007JC004251

Smith WO Jr, Nelson DM (1985) Phytoplankton bloom produced by a receding ice edge in the Ross Sea: spatial coherence with the density Weld. Science 227:163-166

Srikrishnadhas B, Sundararaj V, Ramamoorthi K (1993) Zooplankton of the Porto Novo coastal zone with special reference to invertebrate larvae. J Mar Biol Ass India 35:141-144

Stanwell-Smith D, Hood A, Peck LS (1997) A Weld guide to the pelagic invertebrate larvae of the maritime Antarctic. British Antarctic Survey, Cambridge

Stanwell-Smith D, Peck L, Clarke A, Murray AWA, Todd CD (1999) The distribution, abundance and seasonality of pelagic marine invertebrate larvae in the maritime Antarctic. Phil Trans R Soc Lond B Biol Sci 354:471484

Taki K, Yabuki T, Noiri Y, Hayashi T, Naganobu M (2009) Larval development and spawning ecology of euphausiids in the Ross Sea and its adjacent waters in 2004/05. Plankton Benthos Res 4:135-146

Tanimura A, Fukuchi M, Hoshiai T (1986) Seasonal change in the abundance of zooplankton and species composition of copepods in the ice-covered sea near Syowa station, Antarctica. Mem Natl Inst Polar Res (Spec Issue) 40:212-220

Thorson G (1950) Reproduction and larval ecology of marine bottom invertebrates. Biol Rev 25:1-45

Troncoso JS, Aldea C, Arnaud P, Ramos A, Garcia F (2007) Quantitative analysis of soft-bottom molluscs in the Bellingshausen Sea and around Peter I Island. Polar Res 26:126-134

Vázquez E, Ameneiro J, Putzeys S, Gordo C, Sangrà P (2007) Distribution of meroplankton communities in the BransWeld Strait, Antarctica. Mar Ecol Prog Ser 338:119-129

Weeks AR, GriYths G, Roe H, Moore G, Robinson IS, Atkinson A, Shreeve RS (1995) The distribution of acoustic backscatter from zooplankton compared with physical structure, phytoplankton and radiance during the spring bloom in the Bellingshausen Sea. Deep-Sea Res II 42:997-1019

Young CM (2002) Atlas of marine invertebrate larvae. Academic Press, London 